\title{
Foreword
}

\section{Marianna O'Gallagher}

Volume 50, numéro 1, 1983

Bilan de l'histoire religieuse au Canada

Canadian Catholic History: A survey

URI : https://id.erudit.org/iderudit/1007029ar

DOI : https://doi.org/10.7202/1007029ar

Aller au sommaire du numéro

Éditeur(s)

Les Éditions Historia Ecclesiæ Catholicæ Canadensis Inc.

ISSN

0318-6172 (imprimé)

1927-7067 (numérique)

Découvrir la revue

Citer ce document

O'Gallagher, M. (1983). Foreword. Sessions d'étude - Société canadienne d'histoire de l'Église catholique, 50(1), 1-2. https://doi.org/10.7202/1007029ar

Tous droits réservés @ Les Éditions Historia Ecclesiæ Catholicæ Canadensis Inc., 1983
Ce document est protégé par la loi sur le droit d'auteur. L'utilisation des services d'Érudit (y compris la reproduction) est assujettie à sa politique d'utilisation que vous pouvez consulter en ligne.

https://apropos.erudit.org/fr/usagers/politique-dutilisation/ 


\section{Foreword}

This collection of papers was first presented in September 1983 to a large audience of members of Canadian Catholic Historical Association / Société canadienne d'histoire de l'Église catholique. These historians, both amateur and professional, assembled in Ottawa to celebrate the $50^{\text {th }}$ anniversary of their society.

The three day celebration was opened by Archbishop J.-Aurèle Plourde of Ottawa, at a Mass concelebrated by him with the many priest-members of the society. Archbishop Plourde's homily developed the theme of the historian's role as a helper, a helper in understanding the facts and events that surround us. Whether in Old Testament Times, New Testament times, Vatican II or post-Vatican II, God speaks to us in signs. At first these signs appear as 'a disconnected dust of events, difficult to understand.' It is the historian's role to organize these things into history so that God's people can see His design. 'It is with this perspective of faith,' said the Archbishop, 'than one must look upon the historian's task in order to understand it.'

The exalted level of the compliment to historians, the blessing on their work, and the challenge issued by the Archbishop of Canada's capital city was matched in the following days by the efforts of the presenters. The subjects ranged from historiography itself through event-and-people-history to the history of spirituality old and new in the Canadian Catholic church. It was the intention of the planners to cover the whole spectrum of topics that the journals had carried since they began in 1933, thus the growth of the institutional church as well as the church at work among the people was shown. The French, the Celts, and the later European immigrants were given their pages. How well the congress succeeded will come to be realized only upon the presentation of this volume. The general public should find it interesting. Those who attended the two days at St. Paul's University suffered an 'embarras du choix', hence they especially will welcome the opportunity of reading the ensemble.

The papers for the $50^{\text {th }}$ Anniversary were new examples of the old love of the history of the Church in Canada, and new examples, too, 
of the hard research work needed to enshrine that love in documentation. The Association has always had its scholars: amateurs $(a m o=l o v e)$ and professionals, as the first forty-nine years' publications attest. This golden volume then, appears, thanks to the three-fold efforts of: a team of devoted historians and others, eager to focus attention of the work of the Association, both English and French, lay and religious, men and women worked at all the tasks - academic and logistical; the presenters too who worked to prepare their papers to meet the deadlines of resume and actual speech; and finally, a generous benefactor, the Jackman Foundation whose Board of Governors has watched over CCHA/SCHEC with great benevolence.

Marianna O'GALLAGHER, S.C.H. President CCHA 